\title{
Which Criteria are More Valuable in Defining Hemodynamic Significance of Patent Ductus Arteriosus in Premature Infants? Respiratory or Echocardiographic?
}

Prematüre Bebeklerde Hemodinamik Anlamlı Patent Duktus Arteriyozusun
Tanımlanmasında Hangi Kriterler Daha lyidir? Solunumsal mı Ekokardiyografik mi? İrfan Oğuz Şahin, Canan Yolcu, Ayşegül Elbir Şahin*, Mustafa Kara**, Yaşar Demirelli**, Haşim Olgun, Naci Ceviz

Atatürk University Faculty of Medicine, Department of Pediatric Cardiology, Erzurum, Turkey

*Palandöken State Hospital, Clinic of Anesthesiology and Reanimation, Erzurum, Turkey

**Atatürk University Faculty of Medicine, Department of Neonatology, Erzurum, Turkey

\section{Abstract}

Aim: Patent ductus arteriosus (PDA) is a frequent health problem in premature infants. Pharmacologic closure is recommended only for hemodynamically significant PDA (hsPDA) that is defined according to the clinical and echocardiographic criteria. The aim of this study was to explore the value of commonly used criteria in defining hsPDA and predicting the required number of courses of ibuprofen treatment to close PDA in premature infants.

Methods: Sixty premature infants with a gestational age of $\leq 33$ weeks were evaluated prospectively. Clinical and echocardiographic criteria $\left[\mathrm{O}_{2}\right.$ requirement, ductus diameter $(\mathrm{DD})$ and left atrial-to-aortic root diameter ratio (LA:Ao)] were used to define hsPDA. Clinical improvement after pharmacologic closure of PDA and association between the criteria and required number of ibuprofen courses were investigated.

Results: $\mathrm{O}_{2}$ requirement decreased by PDA closure but was not different between patients with hsPDA and the others with PDA. Also, $\mathrm{O}_{2}$ requirement was not found to be associated with required number of ibuprofen courses. DD and LA:Ao were greater in patients with hsPDA. DD was found to be associated with required number of courses of ibuprofen treatment.

Conclusion: Although there was an improvement in $\mathrm{O}_{2}$ requirement with PDA closure, echocardiographic criteria were found to be more valuable in defining hsPDA. DD should also be used to estimate the duration of treatment.

Keywords: Criteria, patent ductus arteriosus, prematurity
Giriş: Patent duktus arteriyozus (PDA) prematüre bebeklerde sık karşılaşılan bir problemdir. Farmakolojik kapama sadece klinik ve ekokardiyografik kriterlerle tanımlanan hemodinamik anlamlı PDA (haPDA) için önerilmektedir. Bu çalışmanın amacı yaygın olarak kullanılan kriterlerin haPDA tanımlanmasındaki ve PDA kapatıması için gereken ibuprofen kür sayısını tahmin etmedeki değerini incelemektir.

Yöntemler: Gestasyonel yaşı $\leq 33$ hafta olan 60 prematüre bebek prospektif olarak incelenmiştir. Klinik ve ekokardiyografik kriterler $\left[\mathrm{O}_{2}\right.$ ihtiyacı, duktus çapı (DÇ) ve sol atriyumun aort köküne oranı (SA:Ao)] haPDA tanımlanmasında kullanıldı. PDA'nın farmakolojik kapatılmasından sonra klinik düzelme olması ve kriterler ile gereken ibuprofen kür sayıları arasındaki ilişki incelendi.

Bulgular: $\mathrm{O}_{2}$ ihtiyacı PDA kapanması ile azalmakla birlikte bu azalma haPDA olan bebeklerde diğer PDA olan bebeklerden farklı değildi. Ayrıca $\mathrm{O}_{2}$ ihtiyacı ile gereken ibuprofen kür sayısı arasında ilişki bulunmadı. DÇ ve SA:Ao haPDA olan bebeklerde daha büyüktü. DÇ gereken ibuprofen kür sayısı ile ilişkili bulundu.

Sonuç: PDA kapanması ile $\mathrm{O}_{2}$ ihtiyacında düzelme görülmekle birlikte ekokardiyografik kriterler haPDA tanımlanmasında daha değerli bulunmuştur. DÇ ayrıca tedavi süresini tahmin etmede kullanılabilir.

Anahtar Sözcükler: Kriterler, patent duktus arteriyozus, prematürite
Address for Correspondence/Yazışma Adresi: İrfan Oğuz Şahin

Atatürk University Faculty of Medicine, Department of Pediatric Cardiology, Erzurum, Turkey Phone: +90 3623114040 E-mail: rfnshn@yahoo.com

Received/Geliş Tarihi: 18 May 2016 Accepted/Kabul Tarihi: 22 June 2016
${ }^{\circ}$ Copyright 2017 by The Medical Bulletin of Haseki Training and Research Hospital The Medical Bulletin of Haseki published by Galenos Yayınevi. •Telif Hakkı 2017 Haseki Eğitim ve Araştırma Hastanesi Haseki Tıp Bülteni, Galenos Yayınevi tarafından basılmıştır. 


\section{Introduction}

Ductus arteriosus (DA) is the arterial structure between the pulmonary artery and aorta and normally closes spontaneously after birth (1). Patent ductus arteriosus (PDA) is a congenital abnormality in which DA remains open and it is a frequent problem in neonatology units, especially among preterm infants (2). The incidence of PDA is inversely proportional to gestational age (GA) (3). PDA occurs in about one-third of preterm infants, twothirds of extremely low-birth-weight infants and $75 \%$ of those born before 28 weeks of gestation (4-6).

Hemodynamically significant PDA (hsPDA) can result in congestive heart failure, pulmonary edema-bleeding, bronchopulmonary dysplasia, intraventricular hemorrhage, necrotizing enterocolitis, feeding intolerance, and retinopathy in premature infants (7).

The safety and efficacy of closing PDA by pharmacologic agents and surgery are well defined. However, there is not a complete consensus on patient selection and optimal method and timing for closing PDA in premature infants. Also, long-term benefits of closing PDA are still controversial (8). Therefore, PDA treatment strategies differ between centers. The decision whether, when, or how to administer therapies to close PDA in premature infants remains challenging (9). Treatment is commonly prescribed for hsPDA (10).

Most centers use clinical criteria [(a) respiratory signs, including increased respiratory support, failure to wean from respiratory support or $\mathrm{O}_{2}$ need; (b) physical signs, including murmurs, hyperdynamic precordium or bounding pulses; (c) blood pressure problems, including decreased mean or diastolic pressure or increased pulse pressure; (d) signs of congestive heart failure, including cardiomegaly, hepatomegaly or pulmonary congestion] and echocardiographic criteria [(a) a left atrial-to-aortic root diameter ratio of $>1.30$ (LA:Ao); (b) a ductus diameter (DD) of $>1.5-2 \mathrm{~mm}$ ] to define hsPDA but there is a wide variety of strategies used in different clinics (10).

In this study, we aimed to investigate the value of commonly used clinic $\left(\mathrm{O}_{2}\right.$ requirement) and echocardiographic (DD, LA:Ao) criteria in defining hsPDA and in predicting the required number of courses of ibuprofen treatment to close PDA in premature infants.

\section{Methods}

This prospective study was performed in the neonatology department at Atatürk University Faculty of Medicine between October 2011 and April 2013. The study was approved by the local ethics committee. Premature infants with a GA of $\leq 33$ weeks who had hsPDA or insignificant PDA (hiPDA) were included in the study.
Clinical and echocardiographic evaluations were performed to define hsPDA in cooperation with neonatology and pediatric cardiology physicians. We used respiratory problems (respiratory distress, increased $\mathrm{O}_{2}$ or ventilation requirements, tachypnea, hypoxia, and apnea without an evident reason) as clinical criteria and large ductal size $(>1.5 \mathrm{~mm})$ and increased LA:Ao $(>1.4)$ as echocardiographic criteria. M-mode images of the left atrium and aortic root were obtained from a parasternal long-axis view. Ductal sizes were obtained by both B-mode and color Doppler from the high left parasternal view but predominantly the narrowest diameter of color Doppler flow in parasternal short axis view was used to determine the ductal diameter because it is hard to achieve reliable anatomic measurements with B-mode.

Premature infants with hiPDA were followed up only with conservative approaches. In the absence of contraindications, enteral ibuprofen was used to close hsPDA in 60 premature infants.

Enteral ibuprofen was administered via nasogastric tube as courses. Three doses $(10,5$ and $5 \mathrm{mg} / \mathrm{kg}$ ) were accepted as one course and the treatment protocol consisted of up to 3 courses ( 9 doses). Echocardiographic evaluations were performed after courses. In case of hsPDA continuation after 3 courses, patients were referred for surgical closure.

GA, mechanical ventilation parameters, DD, and LA:Ao were recorded during treatment. Echocardiographic investigations were performed by the same physician with a Vivid 7 echocardiography device (General Electric, USA $^{\circledR}$ ) and 10 s probe.

\section{Statistical Analysis}

Descriptive methods (frequency, percentage, mean, standard deviation) were used to analyze data and the Kolmogorov-Smirnov test to analyze normality of distribution. Pearson's chi-square test and Fisher's exact tests were used for comparison of qualitative data. The independent samples t-test was used for quantitative comparison of data between two groups. One-way ANOVA was used for comparison of data between groups more than two. The results were analyzed at a 95\% confidence interval and a $p$ value of less than 0.05 was considered statistically significant.

\section{Results}

$53.3 \%(32 / 60)$ and $48.4 \%(30 / 62)$ of subjects were female and $46.7 \%(28 / 60)$ and $51.4 \%$ (32/62) were male in hsPDA and hiPDA groups, respectively $(p=0.076)$. The mean GA was 29.18 and 29.76 weeks in hsPDA and hiPDA groups, respectively $(p=0.125)$. In two patients, ibuprofen was contraindicated due to necrotizing enterocolitis (one had trombocytopenia also). In these 
patients, successful pharmacologic closure was achieved with paracetamol. Oxygen need was not significantly different between premature infants with hiPDA and hsPDA before PDA closure (Table 1). However, there was a significant difference in $\mathrm{O}_{2}$ requirement of patients after PDA was closed pharmacologically (Table 2). Two patients underwent surgical closure after 3 courses of ibuprofen failed and these patients were not evaluated in terms of oxygen need. DD and LA:Ao were found to be significantly greater in patients with hsPDA and hiPDA (Table 3). There was no significant relationship between the required number of ibuprofen courses to close PDA and $\mathrm{O} 2$ requirement or $\mathrm{LA}: \mathrm{Ao}$ in patients but DD was found to be significantly higher in patients who required 2 and 3 courses than in those required 1 (Table 4).

\section{Discussion}

The relationship of PDA and associated morbidities with utility of closing PDA pharmacologically is subject of discussion and closing PDA pharmacologically is not a standard recommendation for premature infants. Clinicians should weigh the risks associated with medications to close

\begin{tabular}{|c|c|c|c|c|}
\hline & \multicolumn{2}{|c|}{ hiPDA } & \multicolumn{2}{|c|}{ hsPDA } \\
\hline & $\mathbf{n}$ & $\%$ & $\mathbf{n}$ & $\%$ \\
\hline $\mathrm{O}_{2}$ into incubator & 8 & 12.9 & 7 & 11.6 \\
\hline $\mathrm{O}_{2}$ into hood & 5 & 8.0 & 3 & 5.0 \\
\hline CPAP & 38 & 61.3 & 40 & 66.7 \\
\hline SIMV & 11 & 17.8 & 10 & 16.7 \\
\hline Total & 62 & 100 & 60 & 100 \\
\hline \multicolumn{5}{|c|}{$\begin{array}{l}\text { hiPDA: Hemodynamically insignificant patent ductus arteriosus, hsPDA: } \\
\text { Hemodynamically significant patent ductus arteriosus, CPAP: Continuous } \\
\text { positive airway pressure, SIMV: Synchronized intermittent mandatory } \\
\text { ventilation }\end{array}$} \\
\hline
\end{tabular}

\begin{tabular}{|c|c|c|c|c|c|}
\hline & \multicolumn{2}{|c|}{$\begin{array}{l}\text { Before PDA } \\
\text { closed }\end{array}$} & \multicolumn{2}{|c|}{$\begin{array}{l}\text { After PDA } \\
\text { closed }\end{array}$} & \multirow[t]{2}{*}{$p$} \\
\hline & $\mathbf{n}$ & $(\%)$ & $\mathbf{n}$ & $(\%)$ & \\
\hline $\mathrm{O}_{2}$ into incubator & 7 & 11.7 & 9 & 15.5 & \multirow{5}{*}{0.033} \\
\hline $\mathrm{O}_{2}$ into hood & 3 & 5 & 8 & 13.8 & \\
\hline CPAP & 40 & 66.6 & 33 & 56.9 & \\
\hline SIMV & 10 & 16.7 & 8 & 13.8 & \\
\hline Total & 60 & 100 & $58^{\S}$ & 100 & \\
\hline
\end{tabular}

PDA: Patent ductus arteriosus, CPAP: Continuous positive airway pressure, SIMV: Synchronized intermittent mandatory ventilation, Two patients were not included because of surgical closure
PDA versus PDA. The decision of pharmacologic treatment should be based on hemodynamic significance of PDA but this is not always easy to identify $(3,11)$. Many criteria have been used to define hsPDA in premature infants.

In recent publications, it has been shown that electrocardiographic and radiological criteria were nonspecific. Clinical (respiratory signs, physical signs, blood pressure problems, congestive heart failure signs) and echocardiographic (LA:Ao>1.30 and DD>1.5-2 mm) criteria were commonly used to define hsPDAs (10). Unfortunately, the optimal criteria for defining hsPDA are lacking and there is a wide variety of strategies used in different clinics (12). Therefore, the optimal timing of pharmacological treatment for PDA in preterm infants is still controversial (13).

In a study, $29.5 \%, 16.7 \%$ and $53.8 \%$ of patients with hsPDA were found to be on $\mathrm{O}_{2}$ supplement, continuous positive airway pressure and synchronized intermittent mandatory ventilation (1). In our study, $\mathrm{O}_{2}$ requirements were not found to be different between patients with hiPDA and hsPDA (Table 1). This suggests that $\mathrm{O}_{2}$ need was not a good criterion for defining hsPDA.

Some studies reported positive changes in lung compliance in premature infants $(14,15)$ but some

\begin{tabular}{|c|c|c|c|}
\hline & hiPDA & hsPDA & $\mathbf{p}$ \\
\hline LA:Ao & $1.11 \pm 0.48$ & $1.36 \pm 0.27$ & $<0.0001$ \\
\hline Ductal diameter (mm) & $1.65 \pm 0.32$ & $2.25 \pm 0.44$ & $<0.0001$ \\
\hline \multicolumn{4}{|c|}{$\begin{array}{l}\text { hiPDA: Hemodynamically insignificant patent ductus arteriosus, hsPDA: } \\
\text { Hemodynamically significant patent ductus arteriosus, LA:Ao: Ratio of left } \\
\text { atrium to aortic root }\end{array}$} \\
\hline
\end{tabular}

Table 4. Relationship between $\mathrm{O}_{2}$ requirement, ratio of left atrium to aortic root, ductal diameter and required course number of ibuprofen to close patent ductus arteriosus in patients

\begin{tabular}{|c|c|c|c|c|c|c|c|}
\hline & \multicolumn{2}{|c|}{1 course } & \multicolumn{2}{|c|}{2 courses } & \multicolumn{2}{|c|}{3 courses } & \multirow{2}{*}{ p } \\
\hline & $\mathbf{n}$ & $\%$ & $\mathbf{n}$ & $\%$ & $\mathbf{n}$ & $\%$ & \\
\hline $\begin{array}{l}\mathrm{O}_{2} \text { into } \\
\text { incubator }\end{array}$ & 7 & 11.5 & 3 & 5.0 & - & - & \multirow{4}{*}{$\begin{array}{l}0.508 \\
\left(x^{2}=2.321\right)\end{array}$} \\
\hline $\begin{array}{l}\mathrm{O}_{2} \text { into } \\
\text { hood }\end{array}$ & 3 & 5.0 & 1 & 1.7 & - & - & \\
\hline CPAP & 32 & 53.3 & 2 & 3.5 & 1 & 1.7 & \\
\hline \multirow[t]{2}{*}{ SIMV } & 7 & 11.5 & 3 & 5.0 & 1 & 1.7 & \\
\hline & \multicolumn{2}{|c|}{1 course } & \multicolumn{2}{|c|}{2 courses } & \multicolumn{2}{|c|}{3 courses } & $p$ \\
\hline LA:Ao & \multicolumn{2}{|c|}{$1.35 \pm 0.28$} & \multicolumn{2}{|c|}{$1.43 \pm 0.21$} & \multicolumn{2}{|c|}{$1.46 \pm 0.19$} & \multirow[b]{2}{*}{0.381} \\
\hline $\begin{array}{l}\text { Ductal } \\
\text { diameter } \\
(\mathrm{mm})\end{array}$ & \multicolumn{2}{|c|}{$2.18 \pm 0.36$} & \multicolumn{2}{|c|}{$2.62 \pm 0.65$} & \multicolumn{2}{|c|}{$2.76 \pm 0.55$} & \\
\hline
\end{tabular}


reported no difference in respiratory parameters $(16,17)$ after pharmacologic closure of PDA. It is hard to show the isolated effect of PDA closure on respiratory system due to co-affecting factors especially like worsening or ameliorating respiratory distress syndrome, but our study supports that a significant difference in $\mathrm{O}_{2}$ requirement of premature infants could be provided with pharmacological PDA closure (Table 2).

Echocardiographic criteria, such as left ventricular outflow/superior vena cava flow ratio, diastolic and mean flow velocities of the left pulmonary artery, but especially DD and LA:Ao, were found to be adequate and reliable markers of hsPDA $(18,19)$. In our study, DD and LA:Ao were found to be significantly higher in premature infants who needed treatment than in those PDA closed spontaneously (Table 3). This suggests that DD and LA:Ao reflect hemodynamic significance of PDA and could be used in estimating the necessity of pharmacologic treatment of PDA.

Response to pharmacologic agents that were administered to close PDA is related with GA and/or birth weight but do not depend only on those. Despite spontaneous ductus closure in some extremely immature premature infants, some premature large-for-gestationalage infants do not respond to one course of ibuprofen and require additional courses or surgical intervention $(20,21)$. There are multiple factors affecting ductus closure. In our study, the number of ibuprofen courses required to close PDA was not found to be associated with $\mathrm{O}_{2}$ requirement but with DD (Table 4). This suggests that anatomic size of PDA is the most reliable criterion in defining hsPDA and could be used to estimate the duration of treatment to close PDA.

Although high rates of pharmacologic closure are achieved with ibuprofen, it is not completely safe. Paracetamol may be a medical alternative in the management of PDA (22). Paracetamol was used successfully for PDA closure in our two patients who had contraindications for ibuprofen.

\section{Conclusion}

In conclusion, there is a need for an international consensus on criteria for defining hsPDA. Oxygen requirement of premature infants is not different between patients with hsPDA and hiPDA but decreases by PDA closure. Echocardiographic criteria seem more reliable than respiratory criteria in predicting hsPDA and, ductus diameter should also be used to estimate the duration of treatment. Further studies are needed to evaluate the value of each criterion in defining hsPDA.

\section{Ethics}

Ethics Committee Approval: Atatürk University, Ethics Committee of Medicine Faculty, 18.08.2011, meeting number 7, Decision number 19.

Peer-review: Internally peer-reviewed.

\section{Authorship Contributions}

Surgical and Medical Practices: İrfan Oğuz Şahin, Canan Yolcu. Concept: İrfan Oğuz Şahin, Haşim Olgun, Naci Ceviz. Design: İrfan Oğuz Şahin, Canan Yolcu. Data Collection or Processing: İrfan Oğuz Şahin, Mustafa Kara, Yaşar Demirelli. Analysis or Interpretation:Irfan Oğuz Şahin, Ayşegül Elbir Şahin. Literature Search: İrfan Oğuz Şahin, Ayşegül Elbir Şahin. Writing: Irfan Oğuz Şahin, Haşim Olgun, Naci Ceviz.

Conflict of Interest: No conflict of interest was declared by the authors.

Financial Disclosure: The authors declared that this study received no financial support.

\section{References}

1. Terek D, Yalaz M, Ulger Z, Koroglu OA, Kultursaray N. Medical closure of patent ductus arteriosus does not reduce mortality and development of bronchopulmonary dysplasia in preterm infants. J Res Med Sci 2014;19:1074-9.

2. Schneider DJ, Moore JW. Patent ductus arteriosus. Circulation 2006;114:1873-82.

3. Rolland A, Shankar-Aguilera S, Diomandé D, Zupan-Simunek $\checkmark$, Boileau P. Natural evolution of patent ductus arteriosus in the extremely preterm infant. Arch Dis Child Fetal Neonatal Ed 2015;100:55-8.

4. Hamrick SE, Hansmann G. Patent ductus arteriosus of the preterm infant. Pediatrics 2010;125:1020-30.

5. Koch J, Hensley G, Roy L, Brown S, Ramaciotti C, Rosenfeld CR. Prevalence of spontaneous closure of the ductus arteriosus in neonates at a birth weight of 1000 grams or less. Pediatrics 2006;117:1113-21.

6. Narayanan M, Cooper B, Weiss H, Clyman RI. Prophylactic indomethacin: factors determining permanent ductus arteriosus closure. J Pediatr 2000;136:330-7.

7. Cambonie G, Dupuy AM, Combes C, Vincenti M, Mesnage $R$, Cristol JP. Can a clinical decision rule help ductus arteriosus management in preterm neonates? Acta Paediatr 2012;101:213-8.

8. Perez KM, Laughon MM. What is new for patent ductus arteriosus management in premature infants in 2015? Curr Opin Pediatr 2015;27:158-64.

9. Mitra S, Ronnestad A, Holmstrom H. Management of patent ductus arteriosus in preterm infants: where do we stand? Congenit Heart Dis 2013;8:500-12.

10. Zonnenberg I, de Waal K. The definition of a haemodynamic significant duct in randomized controlled trials: a systematic literature review. Acta Paediatr 2012;101:247-51.

11. Abdel-Hady $H$, Nasef $N$, Shabaan AE, Nour I. Patent ductus arteriosus in preterm infants: do we have the right answers? Biomed Res Int 2013;2013:676192.

12. Perez KM, Laughon MM. What is new for patent ductus arteriosus management in premature infants in 2015? Curr Opin Pediatr 2015;27:158-64.

13. Gudmundsdottir A, Johansson S, Håkansson S, Norman $M$, Källen K, Bonamy AK. Timing of pharmacological treatment 
for patent ductus arteriosus and risk of secondary surgery, death or bronchopulmonary dysplasia: a population-based cohort study of extremely preterm infants. Neonatology 2015; 107:87-92.

14. Stefano JL, Abbasi S, Pearlman SA, Spear ML, Esterly $\mathrm{KL}$, Bhutani VK. Closure of the ductus arteriosus with indomethacin in ventilated neonates with respiratory distress syndrome. Effects of pulmonary compliance and ventilation. Am Rev Respir Dis 1991;143:236-69.

15. Gerhardt T, Bancalari E. Lung compliance in newborns with patent ductus arteriosus before and after surgical ligation. Biol Neonate 1980;38:96-105.

16. Krauss AN, Fatica N, Lewis BS, et al. Pulmonary function in preterm infants following treatment with intravenous indomethacin. Am J Dis Child 1989;143:78-81.

17. Morrow WR, Taylor AF, Kinsella JP, Lally KP, Gerstmann DR, delemos RA. Effect of ductal patency on organ blood flow and pulmonary function in the preterm baboon with hyaline membrane disease. Crit Care Med 1995;23:179-86.
18. El Hajjar M, Vaksmann G, Rakza T, Kongolo G, Storme L. Severity of the ductal shunt: a comparison of different markers. Arch Dis Child Fetal Neonatal Ed 2005;90:419-22.

19. Kluckow M, Evans N. Early echocardiographic prediction of symptomatic patent ductus arteriosus in preterm infants undergoing mechanical ventilation. J Pediatr 1995;127:7749.

20. Peckham GJ, Miettinen OS, Ellison RC, et al. Clinical course to 1 year of age in premature infants with patent ductus arteriosus: results of a multicenter randomized trial of indomethacin. J Pediatr 1984;105:285-91.

21. Tekşam Ö, Yiğit Ş, Karagöz T, et al. Oral ibuprofen and intravenous indomethacin for treatment of patent ductus arteriosus in newborn infants: retrospective study. Turk J Ped 2004;47:96-102.

22. Oncel MY, Yurttutan S, Erdeve $\mathrm{O}$, et al. Oral paracetamol versus oral ibuprofen in the management of patent ductus arteriosus in preterm infants: a randomized controlled trial. J Pediatr 2014;164:510-4. 